\title{
Innovation in Retrospect: An Exploratory Study of Trends in the Levels of Innovation
}

\author{
Stav Rosenzweig ${ }^{1}$ \\ 1 The Department of Management, The Guilford Glazer Faculty of Business and Management, Ben-Gurion \\ University of the Negev, Israel \\ Correspondence: Stav Rosenzweig, The Department of Management, The Guilford Glazer Faculty of Business \\ and Management, Ben-Gurion University of the Negev, Israel. Tel: 972-8-647-9739. E-mail: \\ stavro@som.bgu.ac.il
}

Received: June 29, 2015

doi:10.5539/ijbm.v10n10p63

Accepted: August 24, $2015 \quad$ Online Published: September 18, 2015

URL: http://dx.doi.org/10.5539/ijbm.v10n10p63

The research was partially supported by the Israel Foundation Trustees.

\begin{abstract}
The 20th century was characterized by growing trends of consumption and the introduction of new products that offered consumers various levels of innovation. The abundance of new products made technological innovation a central characteristic of 20th century consumer culture. Interestingly, when reflecting upon outstanding innovations of the 20th century, many of these seem to have been innovated during its early rather than late decades. The present exploratory study examines the occurrence of trends in the level of innovation in the 20th century. Using two complementary studies based on both objective and subjective innovation measures, our findings suggest that (1) trends in the level of innovation are observable and vary across industries, and (2), generally speaking, the level of innovation seems to be higher in the early decades of the 20th century, with the two different analyses indicating a decline in the level of innovation toward the end of the 20th century.
\end{abstract}

Keywords: innovation trends, innovation levels, patents, historical approach

\section{Introduction}

The 20th century was characterized by growing trends of consumption and the introduction of new products destined to satisfy the needs and wants of consumers (Lawrence, 1993). New products offered consumers various levels of innovation, and the abundance of these new products made technological innovation a central characteristic of 20th century consumer culture. What were the most outstanding innovations of the 20th century? Home refrigeration? The radio? Television? Digital computers? The airplane? The air conditioner? The razor? The Band-Aid? Indeed, not only were these products innovative when they were first introduced, but they also had a significant impact on a daily basis on the way consumers act and think. It would therefore be interesting to note that all of these innovations, and perhaps a large portion of the other outstanding innovations of the 20th century, were innovated during its first half. Can it be that many of the innovations that still affect our lives today were innovated during the first half of the 20th century, while the second half was less innovative? Is there a "big picture" that we might be missing?

Managers and scholars tend to focus on specific innovations or specific firms. The majority of innovation studies focus on the firm level. However, by focusing on the single innovation level or on the firm level, it is easy to miss the "big picture". Realizing the existence of a "big picture" is important, because firms spend billions of dollars on R\&D and innovation. If managers of firms are unaware of "big picture" forces that may affect their innovation efforts, it is likely that their innovation-related decisions will overlook important information, possibly rendering their innovation-related decisions suboptimal. The amount of money invested in innovation activity warrants this extra attention to the "big picture".

The present exploratory research aims to answer the following research question: Can one identify macro-level trends in the levels of innovation over time? To answer the research question, we conducted two longitudinal studies. The first study focuses on objective measures of patenting activity during the course of 15 years. The second study focuses on a longitudinal historical study of prominent innovations introduced to the US market 
during the 20th century, focusing on subjective aspects such as perceived innovativeness. The studies substantially differ in the methodology they employ and the length of the period they examine. Their ultimate objective is to provide synoptic evidence for the existence of trends in innovation levels, as can be observed only in retrospect.

Combined together, the results of our two studies indicate a decrease in the levels of innovation during the second half of the 20th century in most-though not all-technological categories. In light of the growth in the adoption of longitudinal methods in the study of innovation (Perks \& Roberts, 2013), the present research offers a new longitudinal perspective of innovation trends over time. More importantly, the present exploratory research may indicate the importance of the context in which innovation advances, in line with recent research suggesting that innovation advances with the development of society and the economy (Marques, 2014).

Thus far, studies that examined innovation-related trends focused on specific product categories, or specific industries. They have also examined a specific period, usually a limited one. The present study aims at bridging this gap in the literature by examining (1) multiple industries: study 1 examines 10 industries and assesses each one independently, and study 2 augments innovations from 9 industries; and (2) two periods: study 1 examines 15 years and study 2 takes a more general, "zoom-out” look at 1900-1999.

\section{Literature Review}

\subsection{Longitudinal Studies of Innovation}

The use of a longitudinal perspective in the study of innovation focuses on research activities that occurred in the past, in order to design holistic views of innovation processes (Perks \& Roberts, 2013). Longitudinal aspects of product and technological innovations have long been of interest to scholars. For example, prior studies examined changes in product life cycles (PLC) over time. Qualls, Olshavsky, and Michaels (1981) test the commonly held assumption that PLCs shorten over time, provide evidence for the shortening of both the introductory and growth stages, and suggest that macro-level variables, such as changes in the prices of goods or variations in consumers' household characteristics, drive this shortening. Schultz and Rao (1986) show that changes in macro-economic conditions, such as changes in the prices of goods or fluctuations in income levels, can affect the length of PLCs. Foster, Golder, and Tellis (2004) suggest that the growth stage has not shortened over time, however the time to take-off for certain products, i.e., the transition into the growth stage, shortened after World War II. This observed shortening of PLC sections suggests an acceleration in adoption patterns (Qualls et al., 1981) or in the patterns of technological change over time (Gregan-Paxton et al., 2002; Gregan-Paxton \& Roeder John, 1997; Sood \& Tellis, 2005).

Complementary to the patterns suggested by PLC literature, diffusion literature points to an acceleration in the diffusion speed of consumer products, which is affected by macro-level variables, such as changes in employment patterns and in disposable income per household, or demographic changes (Van Den Bulte, 2000). Kohli, Lehmann, and Pae (1999) suggest that the apparent acceleration in diffusion patterns noted above is affected by a growing tendency of new products to imitate existing products and technologies. Similarly, Bayus (1994; 1998) suggests that the shrinkage in PLCs stems from a growing tendency of new products to be mere incremental improvements of old ones, and from the growing extent of the reliance of new products on old technologies.

The tradition of examining innovation over time is evident in more recent studies as well. For example, Artz, Norman, and Cardinal (2010) point to an observed increase in patenting activity over time, and attribute this to the growing tendency of firms to use patents as strategic weapons. Antonelli, Crespi, and Scekkati (2013) suggest that changes in innovation patterns over time could be the result of strategic orientations of firms that adopt past-dependence or path-dependence-strategic tendencies that may change over time.

Based on the above literature review and scholarly evidence, we suggest that trends in the level of innovation are likely to occur, and that such trends may very well stem from changes in economic and social conditions that are observable only when zooming-out of a specific context, that is, only when considering a macro-level perspective in retrospect. Figure 1 exhibits our conceptual model. 


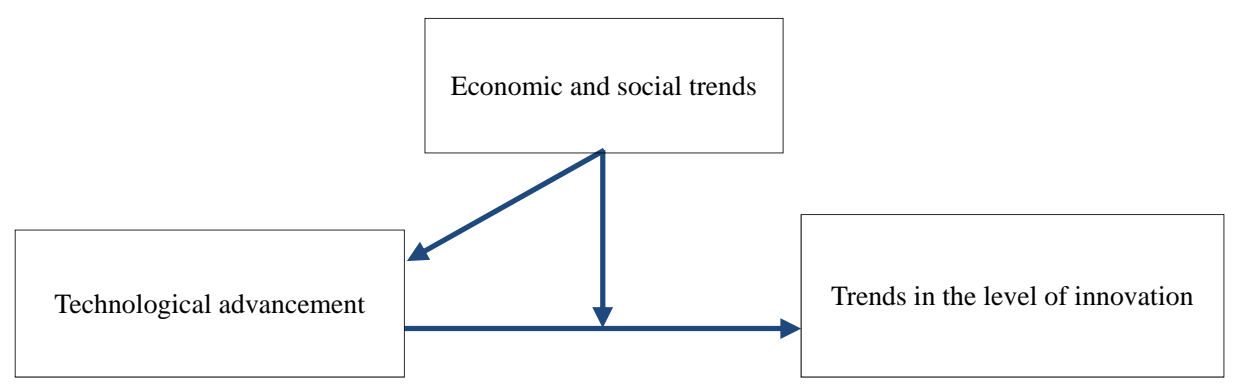

Figure 1. Conceptual model

\section{Study 1-Trends in the Levels of Innovation across Industries}

The purpose of this study is to examine the existence of trends in the level of innovation over time, using objective measures and examining a number of industries.

\subsection{Method}

Patenting data are frequently used in management studies to measure innovation indicators such as R\&D outputs, innovation performance, quality, etc. (e.g., Artz et al., 2010; Chatterji \& Fabrizio, 2014; Rosenzweig \& Mazursky, 2014; Van De Vrande, 2013). Patent entries are a formal record that ascribes intellectual property rights to the inventor(s) of a patent. A patent entry must include citations of previous patents that the current patent builds upon. Whereas these patent citations serve the legal purpose of accurately ascribing intellectual property rights to patent owners according to their precise contribution to innovation, patent citations can also indicate a patent's quality or innovativeness (e.g., Audia \& Goncalo, 2007; Chandy, Hopstaken, Narasimhan, \& Prabhu, 2006; Lanjouw \& Schankerman, 2004; Rosenzweig \& Mazursky, 2008; Sorescu, Chandy, \& Prabhu, 2007). The more a patent is cited by subsequent patents, the more it contributes to the evolution of technology and thus the more innovative it is. Accordingly, prior studies have used patent citations to measure innovativelness of technological output, usefulness-and even economic value-of innovations (e.g., Aghion, Bloom Blundell, Griffith, \& Howitt, 2005; Benner \& Tushman, 2002; Rosenzweig \& Mazursky, 2014; Trajtenberg, 1990). Because the US patenting system provides a global standard for patenting, and a patent granted in the US is likely to be protected by international law in other countries (Trajtenberg, 2001), we choose to examine patents in the US, which enables patenting by inventors from multiple countries. We used the National Bureau of Economic Research patent data, and examined all the patents granted by the US patent office between 1975 and 1990 in 10 different industries, totaling 242,503 patents (Table 1).

Table 1. Industries and technological subcategories included in the study*

\begin{tabular}{llll}
\hline & Industry & $\begin{array}{l}\text { Industry } \\
\text { code* }\end{array}$ & $\begin{array}{l}\text { Number } \\
1975-1990\end{array}$ \\
\hline 1. & Chemical Patents in Agriculture, Food, Textiles & 11 & 11,560 \\
2. & Communications & 21 & 42,222 \\
3. & Computer Hardware \& Software & 22 & 24,605 \\
4. & Computer Peripherals & 23 & 7,235 \\
5. & Information Storage & 24 & 16,156 \\
6. & Electrical Devices & 41 & 35,419 \\
7. & Transportation & 55 & 34,935 \\
8. & Agriculture, Husbandry, Food & 61 & 25,876 \\
9. & Apparel \& Textile & 63 & 21,085 \\
10. & Furniture, House Fixtures & 65 & 23,410 \\
Total number of patents included in the study & & $\mathbf{2 4 2 , 5 0 3}$ \\
\hline
\end{tabular}

*Industry codes and names are adapted from Hall, Jaffe, \& Trajtenberg (2002), and based on the USPTO classifications.

We measure the level of innovation using the average number of forward citations, i.e., citations received from future patents (Trajtenberg, 1990): 


$$
\text { Level_of _ Innovation }{ }_{j t}=\frac{\sum_{i=1}^{n_{j t}}\left(1+\text { Forward _ citations }{ }_{i}\right)-n_{j t}}{n_{j t}}
$$

where $i$ is a patent, $j$ is industry, $t$ is the year a patent was granted, and $n$ is the number of patents applied for in industry $j$ in year $t$. The patents in our sample were granted between 1975 and 1990. But it takes time for a patent to be cited by subsequent patents, and for this reason we count the citations these patents received in 1999. We choose this point in time for the following reasons. First, Hall, Jaffe, and Trajtenberg (2002) suggest using a long enough backward time in citation counts to avoid truncation bias. Second, prior innovation research focusing on patent citation counts used a similar backward time window (Furman, Porter, \& Stern 2002; Lanjouw \& Schankerman, 1999). For example, Rosenzweig and Mazursky (2014) find that a patent granted between 1975 and 1990 took an average of 9 years to be cited. Thus, our choice of 1999 as the year of innovation measure ensures that both the early (1975) and late (1990) patents in our sample have adequate time and probability to be cited by future patents. Third, choosing 1999 as the year of determining the level of innovation is consistent with our intention of detecting innovation trends within the time frame of the $20^{\text {th }}$ century. Patent citations are not biased, because inventors have no incentive to over- or under-cite prior technologies that they relied on, but for a patent to be granted inventors must be meticulous in citing every patent on which their work was based (Chandy et al., 2006). At the same time, unlike citations of academic work, there is no incentive for inventors to cite patents of friends or of famous inventors (Gomes-Casseres, Hagedoorn, \& Jaffe, 2006). To examine the existence of trends in the level of innovation, we plotted the average citation counts of each industry over time (see Figures 2-4).

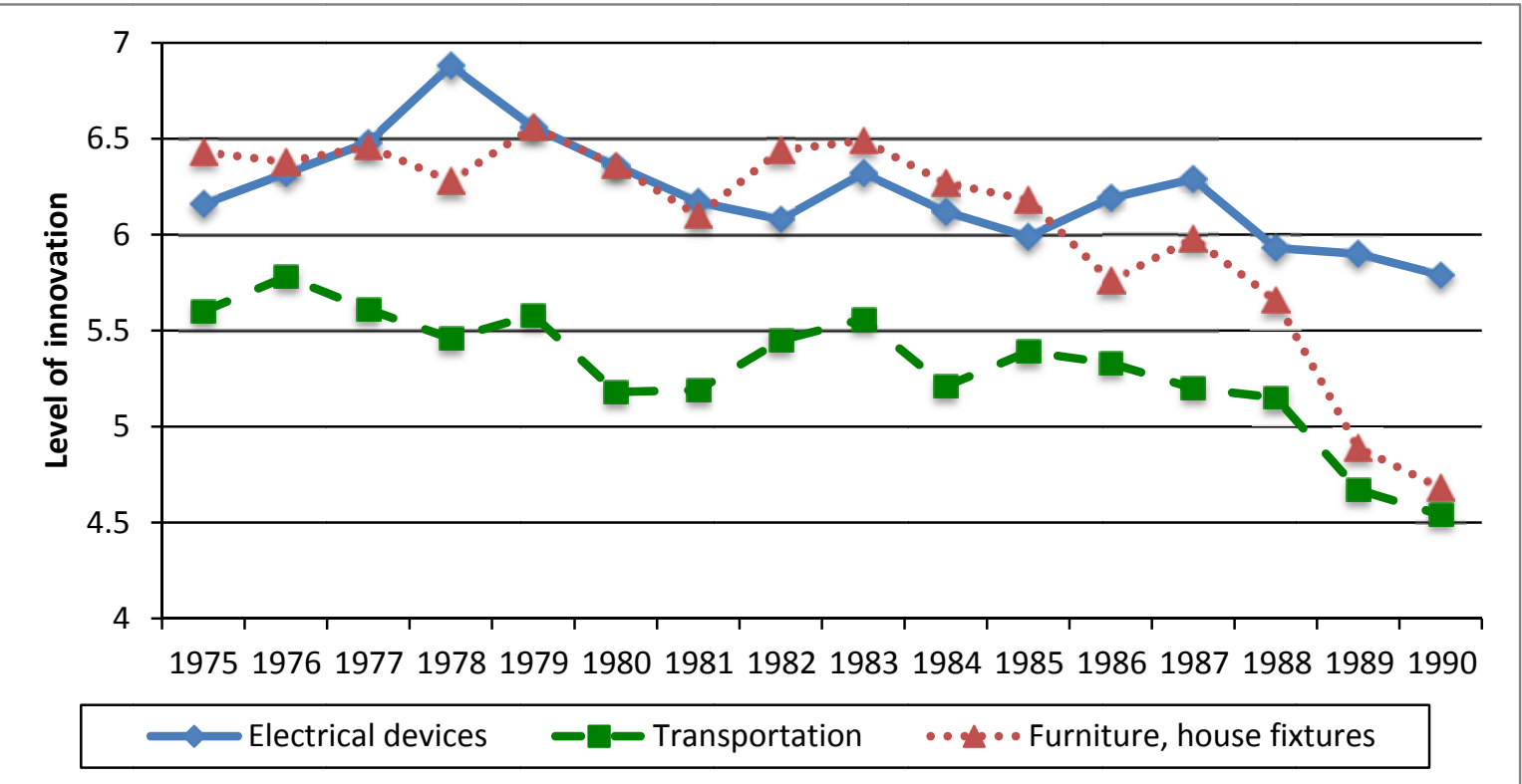

Figure 2. Levels of innovation over time according to patent citations in electrical devices, transportation, and furniture and house fixtures 


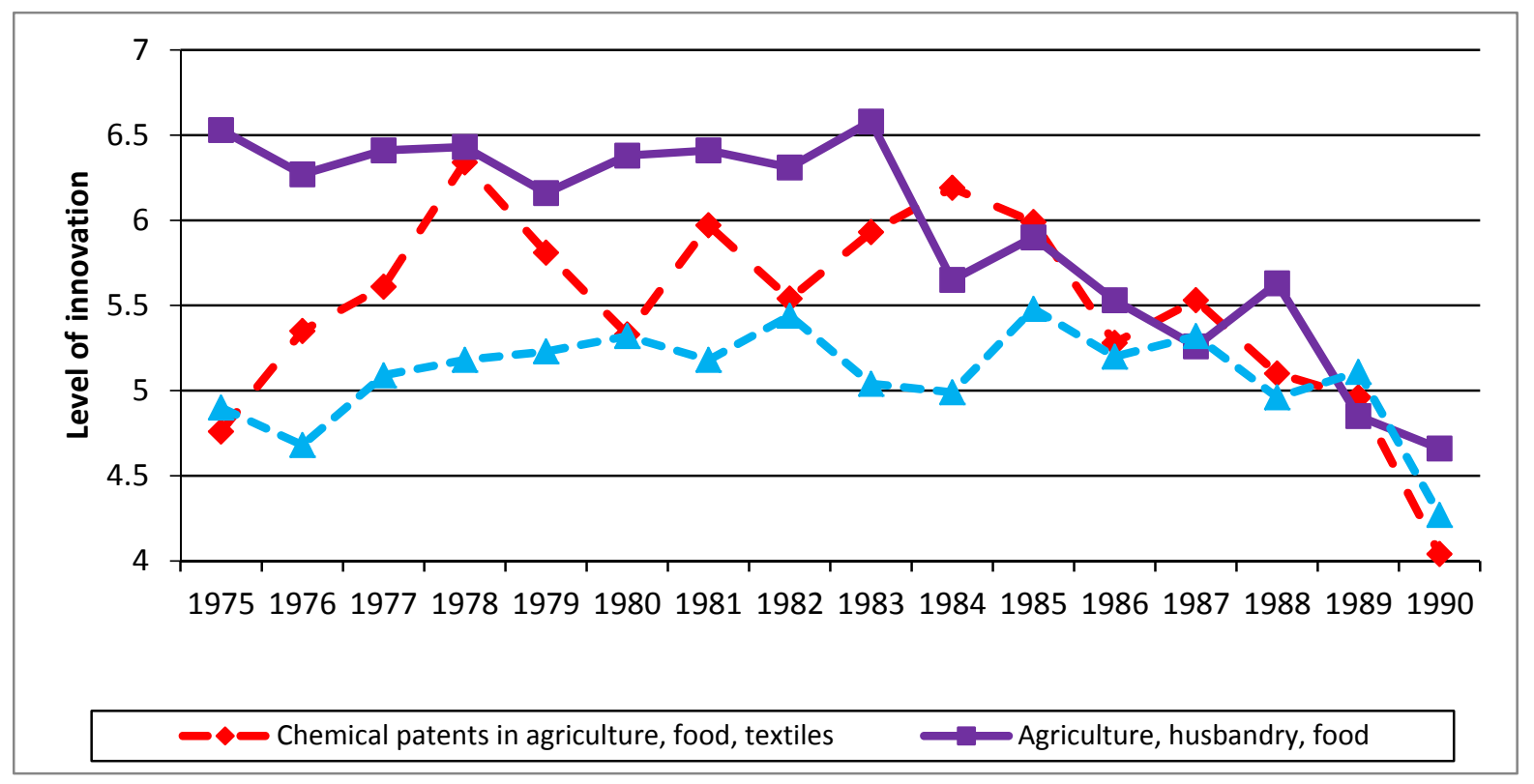

Figure 3. Levels of innovation over time according to patent citations in apparel and textile, agriculture, husbandry, and food, and chemical patents: agriculture, food, and textile

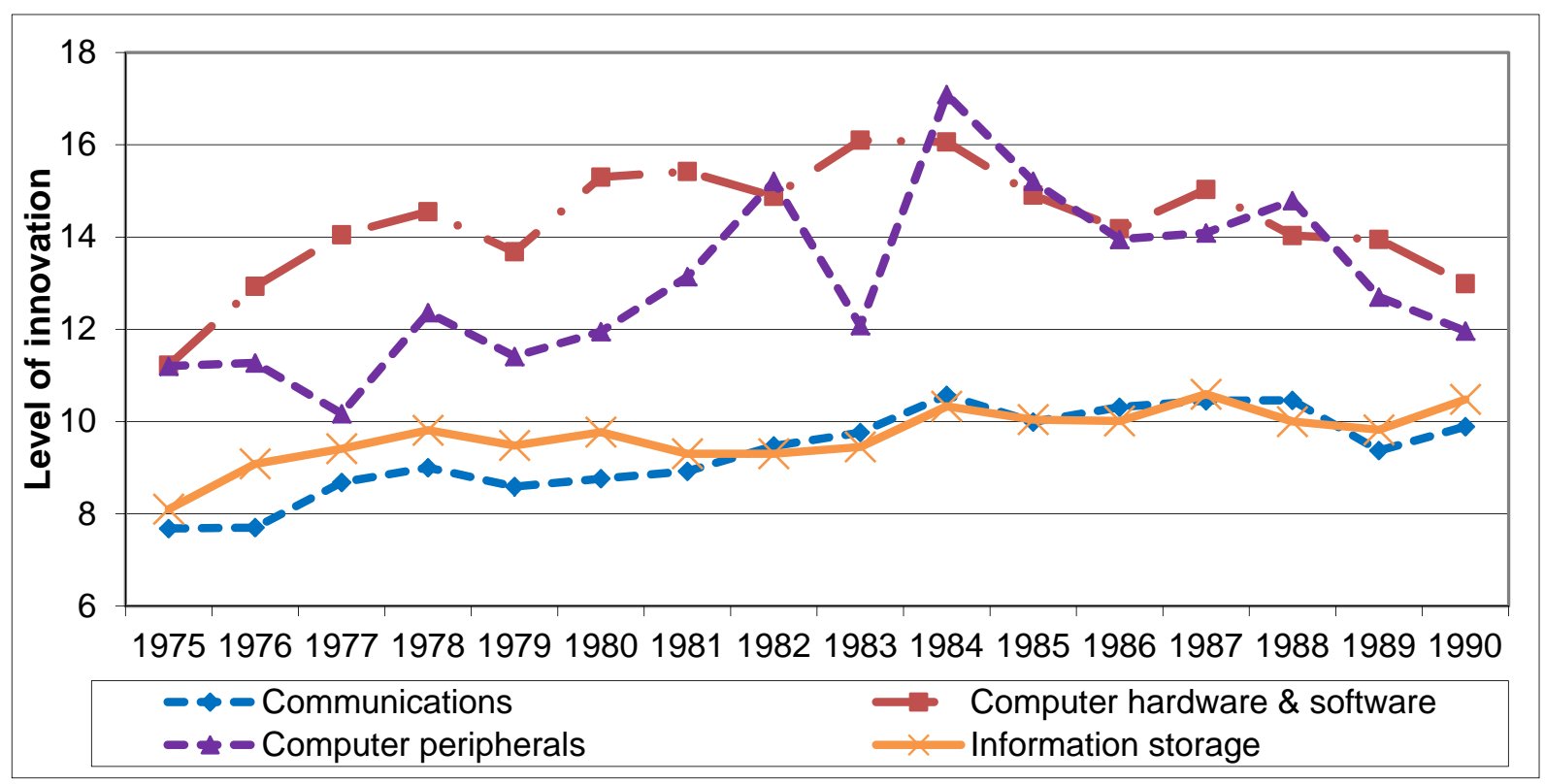

Figure 4. Levels of innovation over time according to patent citations in communications, hardware and software, computer peripherals, and information storage

\subsection{Findings and Discussion}

Figures 2-4 exhibit the average levels of innovation by years. A number of observations can be derived from these figures. First, different industries exhibit different levels of innovation. That is, some industries adhere to innovation standards that differ from other industries. For example, the apparel and textile industry exhibits innovation levels far lower than the computer peripherals industry (with an average citation count of around 5 for the former, vs. 12 for the latter). Second and more profound is the fact that one can identify increasing or decreasing trends in the level of innovation across industries. For example, patents in the food or chemical industries exhibit a decreasing trend in the level of innovation during the examined period. A similar decreasing trend is observable for transportation and electrical devices. In contrast to these clear trends of a decrease in 
innovation levels, computation and communications industries exhibit an increasing pattern. Whereas it is hard to determine a clear increasing or decreasing trend for computer peripherals or computer hardware and software, both communications and information storage industries exhibit a small but steadily increasing trend of innovation levels over the examined period.

The seminal work of Trajtenberg (1990) demonstrated that citation counts are an excellent approximation of the economic value of a patent. In light of this notion, one can argue that the economic value in certain industries decreased between 1975 and 1990, whereas the economic value in the communications and information storage industries increased.

Objective economic value, however, provides only a part of the picture. Objective measures may be insufficient in uncovering social perceptions. The subjective perception of customers, and of the marketplace as a whole, is missing. When it comes to innovation, the way the market perceives the innovation (customers, opinion leaders, competitors, media, etc.) could be just as important - or even more - than objective measures. Instead of asking to what extent the product is innovative in objective terms and economic value, one can learn a great deal from the extent to which customers perceive a product as innovative when they first encounter it. The customer perspective is very important, however quite challenging, given that we are interested in a retrospective as well as longitudinal view of innovation. We address these challenges in the following section.

\section{Study 2-Longitudinal Trends in the Level of Innovation}

The purpose of this study is to examine innovation trends in a way that captures the subjective point of view of the market. It also is designed to cover a time range wide enough to grasp trends of changes-if any-in the levels of innovation over a longer period than that examined in study 1 , a period that attempts to capture innovations from as early as the beginning of the $20^{\text {th }}$ century. The far-back retrospective is exceptionally valuable if one wishes to consider long-term consequences of innovations (e.g., Coviello \& Joseph, 2012; Hargadon \& Douglas, 2001). As Hargadon and Douglas put it, "Historical cases can provide the necessary distance to observe how an innovation both emerges from and reshapes its institutional environment” (2001, p. 476). Accordingly, we use an historical approach. This approach provides a perspective that is richer than that of other methods, and enables the examination of norms, values, and beliefs. For these reasons, the historical approach is valuable when examining the context of innovation, a primary goal of the present research.

\subsection{Method}

\subsubsection{Sample}

To generate a sample of innovation with minimum bias, we searched thoroughly for publically published lists of the most prominent innovations of the 20th century in terms of both success and failure. The logic behind this search is that if writers, editors, and customers note certain innovations as the most successful or the most failed, then these innovations are remembered over time and thus were very impactful. We have identified 17 published lists, with a total of 598 prominent consumer-related innovations. To generate an adequate representation of older and newer innovations, we classified the innovations into nine general industries based on a US patent office classification (Hall et al., 2002). To equally represent industries and decades, we randomly sampled innovations from industries and decades, using stratified sampling. Within each decade, we classified the innovations into industries, and then from each decade and industry we sampled innovations in proportion to the patents issued by the USPTO during this decade for this industry. For example, if between 1950 and 1959, 20\% of the patents in the US were granted for textile patents and $15 \%$ were granted for communications patents, then from that decade we randomly sampled approximately $20 \%$ textile innovations and $15 \%$ communications innovations. Altogether, we randomly sampled 125 innovations from nine industries, commercialized in the US between 1900 and 1999 . Our sample includes what may be considered radical innovations, such as air conditioning and the vacuum cleaner and less radical innovations such as the Band-Aid, as well as high-tech innovations such as the 1968 Picture Phone and low-tech innovations such as Barbie (note that the former was a failure and the latter a success), indicating the diversity of the sampled innovations. The final sample is in line with prior research that used the historical approach in investigating a specific group of innovations of special interest (e.g. Golder, 2000; Golder, Shacham, \& Mitra, 2009).

\subsubsection{Data Collection}

For each of the sampled innovations, we collected information using an historical approach (see Fullerton, 2011; Golder, 2000; Golder, 2009; Hargadon \& Douglas, 2001; Sood \& Tellis, 2005). The historical approach is a systematic and structured approach that includes the examination of multiple sources of information, and then carefully evaluates each source, considering its credibility and reliability, and to what extent the same 
information reappears in more than one source (Golder, 2000). Our sources were patent documentations, peer-reviewed articles, books, biographies of inventors, magazine articles, company websites, and online archives. The variety of sources, along with their diverse nature, enables insights and richness of details, especially because it requires the investigator to consider not only the event but also its full context. The emphasis on the context of the historical approach, and the fact that it is very useful for exploring longitudinal occurrences and changes over time (e.g., Golder, 2000; Smith \& Lux, 1993), make the historical approach exceptionally apt for investigating trends in innovation levels.

Adhering to the systematic and structured historical approach, we used information only after establishing the reliability and credibility of the source according to the criteria of the method, and after crosschecking any evidence critical for the evaluation of the innovation. We then formulated standard descriptions of the innovations, and after reviewing prior studies in major journals such as Science, Management Science, Journal of Marketing Research, and Journal of Marketing (e.g., Chandy \& Tellis, 2000; Goldenberg, Lehmann, \& Mazursky, 2001; Goldenberg, Mazursky, \& Solomon, 1999a; 1999b), we had four experts evaluate the innovations based on the descriptions we provided. Our four experts had teaching, research, or practical experience in innovation. Still, due to the variety of innovations examined and because we wanted to ensure that all experts were exposed to consistent information, we followed Chandy and Tellis (2000) and Goldenberg et al. (2001) and gave the experts detailed information on each of the innovations we sampled and asked them to rate the innovations. The experts were unaware of the hypotheses of the study, and each of them viewed all of the innovation descriptions.

\subsubsection{Measures}

The experts were asked to evaluate the innovations' characteristics from the perspective of the market as can be learned from the historical records. The experts rated the innovations on a seven-point scale item adapted from Moreau, Lehmann, and Markman (2001) assessing the level of innovation compared with existing products. The inter-rater reliability for this item was .81. Similarly, the experts rated the innovations on two seven-point scales for the extent to which the innovation changed existing markets and the extent to which the innovation generated new markets. The inter-rater reliabilities for these items were .83 and .80 , respectively.

\subsection{Discussion of Findings}

Figure 5 exhibits the average levels of innovation that the experts attributed to innovations, based on the historical records we provided them, by decades. Figure 6 exhibits the attributed extent to which the innovations changed existing markets and generated new markets.

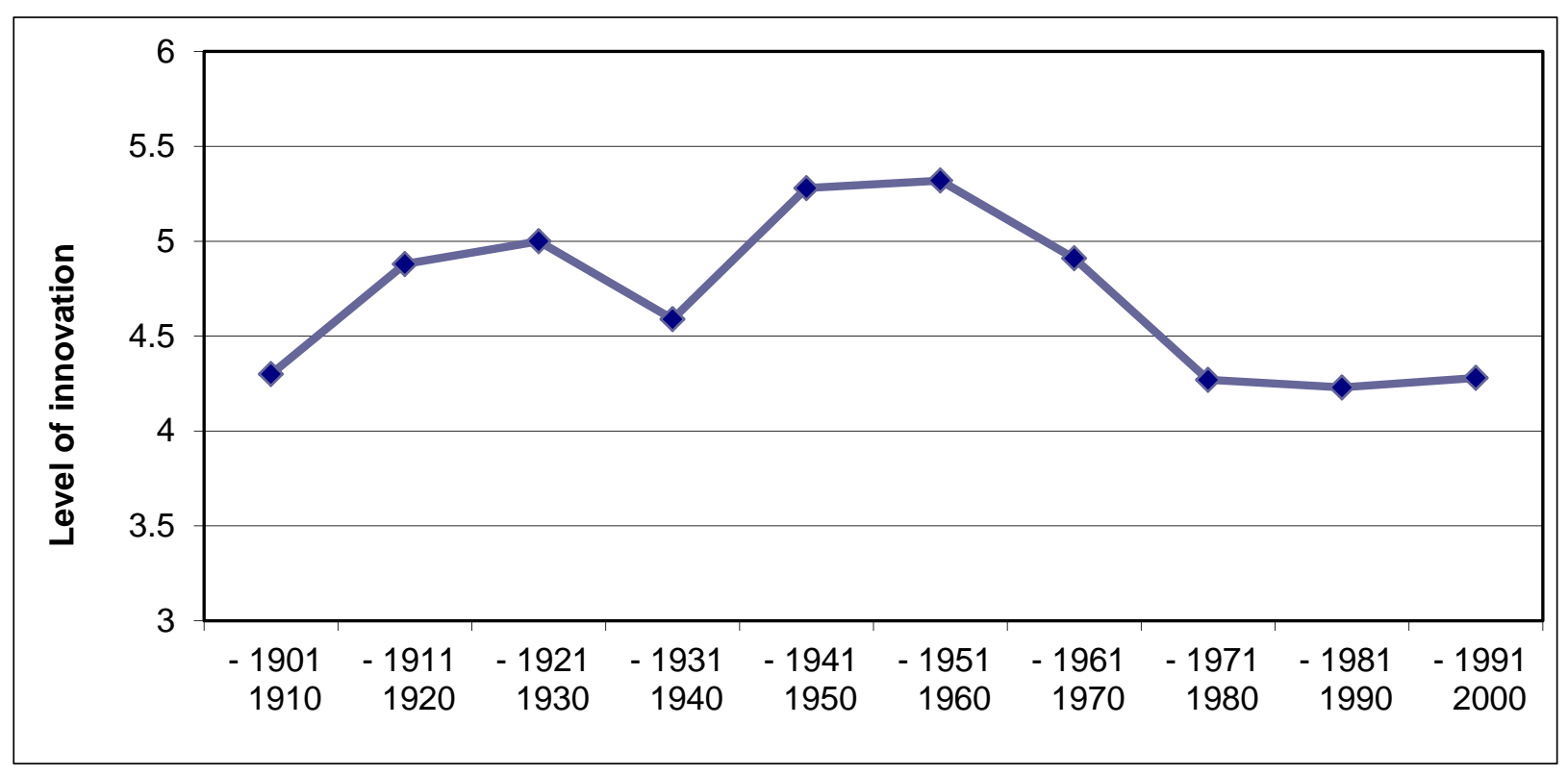

Figure 5. Levels of innovation over time according to historical records 


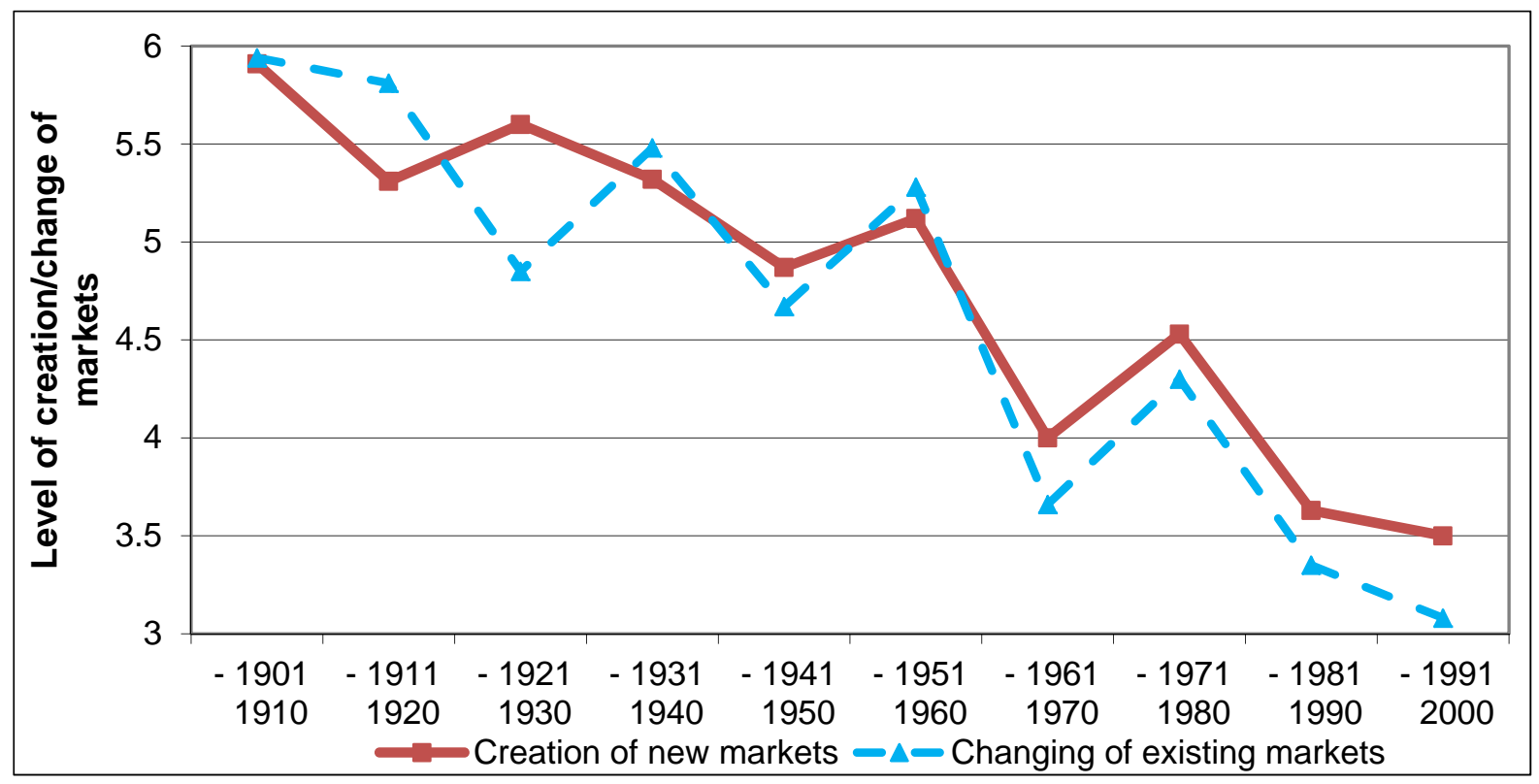

Figure 6. The extent to which innovations changed existing markets and generated new markets according to historical records

Examining the consumers' and market point of view regarding the level of innovation exhibited by the sampled innovations reveals a tendency of trends in innovation levels: innovations introduced to the market in the four last decades of the $20^{\text {th }}$ century demonstrate a decreasing trend, whereas innovations introduced during the first half of the $20^{\text {th }}$ century do not demonstrate such a trend (Figure 5). Whereas a minor decline in innovation levels seems to be observed between the two World Wars, this decrease is not statistically significant. Moreover, the extent to which innovations change existing markets and generate new markets also seems to decrease over time (Figure 6). The interpretation of these findings must be cautious, because we sample a limited number of innovations relative to the long examined period. The strength of these results is evident when combined with the results of study 1 , because despite the use of a dramatically different methodology and perspective, the findings are in line with one another, indicating the existence of longitudinal trends in the levels of innovation.

\section{Conclusion}

Innovation is one of the most influencing factors in the success and failure of a new product (see Baker, Sinkula, Grinstein, \& Rosenzweig, 2014; Cooper, 1984; Cooper \& de Brentani, 1991; Szymanski, Kroff, \& Troy, 2002). Whereas the 20th century appears to have been one of increasing innovation in terms of more patents granted and more products introduced (Artz et al., 2010; Lawrence, 1993), it also seems that many of these patents and products are mere modifications of existing products, and thus offer a limited extent of innovation (Audia \& Goncalo, 2007; Bayus, 1994; 1998; Kohli et al., 1999). The current exploratory study demonstrates the merit of using a broader perspective that can complete the detailed picture provided by examining single innovations or single firms. Using a broader perspective enables us to evaluate the role of context, whether economical, technological, or social. That is, changes in innovation levels are not necessarily unique or singular events. One may think they are unique, but examining the "big picture" enables one to detect more general trends. If the context is ignored, one might mistakenly attribute such changes to a specific firm, product, or R\&D team, rather than to more general trends. A focus on the context rather than on a singular innovation event enables a new and refreshing viewpoint, which may be less plausible when examining details. Whereas thus far entrepreneurs have considered primarily micro-level variables, such as the marketing mix and characteristics of the specific innovation, when deciding whether to invest in an innovative product or technology, results suggest that macro-level considerations should be taken into account as well.

The two studies we present here are complementary and together provide a comprehensive picture of both objective and subjective measures and industry and product levels, and a study of objective economic measures and a substantial data set, as well as a longitudinal study of a historical nature.

The contributions of this research are as follows. First, whereas our two studies do not examine the causality 
between macro-economic or macro-social trends and trends in innovation, our results may raise awareness to a "big picture" that might have a considerable effect on innovation. Future research can examine such causalities and determine if economic, social, or other trends play a meaningful role in the generation of trends of innovation over time. For example, Rosenzweig and Mazursky (2014) and Xie and Liu (2015) recently suggested that global integration may lead to changes in innovation-related trends. Second, one can measure the level of innovation using objective, rigorous measures, such as patent citations. The downside of using this measure is that it is not holistic, primarily because it ignores consumer perceptual factors and the actual acceptance of an innovation in the marketplace. Our second study examines innovations that were actually commercialized, rather than patents or innovations that may have remained merely ideas. Some scholars do not even consider non-commercialized technologies as innovation, but rather as mere invention (Marques, 2014). Indeed, in many cases patents and ideas do not mature into working products, but remain passive knowledge that does not translate into further technological evolution (Golder et al., 2009; Trajtenberg, 1990). Accordingly, we contribute to the study of innovation by asserting that a combination of perceptual innovation indicators and objective measures can provide a more nuanced picture, especially for longitudinal aspects of innovation.

\section{References}

Aghion, P., Bloom, N., Blundell, R., Griffith, R., \& Howitt, P. (2005). Competition and innovation: An inverted-U relationship. The Quarterly Journal of Economics, 120(2), 701-728. http://dx.doi.org/10.3386/w9269

Antonelli, C., Crespi, F., \& Scellato, G. (2013). Internal and external factors in innovation persistence. Economics of Innovation and New Technology, 22(3), 256-280. http://dx.doi.org/10.1080/10438599.2012.708135

Artz, K. W., Norman, P. M., Hatfield, D. E., \& Cardinal, L. B. (2010). A longitudinal study of the impact of R\&D, patents, and product innovation on firm performance. Journal of Product Innovation Management, 27(5), 725-740. http://dx.doi.org/10.1111/j.1540-5885.2010.00747.x

Audia, P. G., \& Goncalo, J. A. (2007). Past success and creativity over time: A study of inventors in the hard disk drive industry. Management Science, 53(1), 1-15. http://dx.doi.org/10.1287/mnsc.1060.0593

Baker, W. E., Sinkula, J. M., Grinstein, A., \& Rosenzweig, S. (2014). The effect of radical innovation in/congruence on new product performance. Industrial Marketing Management, 43(8), 1314-1323. http://dx.doi:10.1016/j.indmarman.2014.08.005

Bayus, B. L. (1994). Are product life cycles really getting shorter? Journal of Product Innovation Management, 11(4), 300-308. http://dx.doi.org/10.1111/1540-5885.1140300

Bayus, B. L. (1998). An analysis of product lifetimes in a technologically dynamic industry. Management Science, 44(6), 763-775. http://dx.doi.org/10.1287/mnsc.44.6.763

Benner, M. J., \& Tushman, M. (2002). Process management and technological innovation: A longitudinal study of the photography and paint industries. Administrative Science Quarterly, 47(4), 676-706. http://dx.doi.org/10.2307/3094913

Chandy, R. K., \& Tellis, G. J. (2000). The incumbent's curse? Incumbency, size, and radical product innovation. Journal of Marketing, 64(3), 1-17. http://dx.doi.org/10.1509/jmkg.64.3.1.18033

Chandy, R. K., Hopstaken, B., Narasimhan, O., \& Prabhu, J. (2006). From invention to innovation: Conversion ability in product development. Journal of Marketing Research, 43(3), 494-508. http://dx.doi.org/10.1509/jmkr.43.3.494

Chatterji, A. K., \& Fabrizio, K. R. (2014). Using users: When does external knowledge enhance corporate product innovation? Strategic Management Journal, 35(10), 1427-1445. http://dx.doi.org/10.1002/smj.2168

Cooper, R. G. (1984). How new product strategies impact on performance. Journal of Product Innovation Management, 1(1), 5-18. http://dx.doi.org/10.1111/1540-5885.110005

Cooper, R. G., \& Brentani, U. (1991). New industrial financial services: What distinguishes the winners. Journal of Product Innovation Management, 8(2), 75-90. http://dx.doi.org/10.1111/1540-5885.820075

Coviello, N. E., \& Joseph, R. M. (2012). Creating major innovations with customers: Insights from small and young technology firms. Journal of Marketing, 76(November), 87-104. http://dx.doi.org/10.1509/jm.10.0418

Foster, J. A., Golder, P. N., \& Tellis, G. J. (2004). Predicting sales takeoff for Whirlpool’s new personal valet. 
Marketing Science, $\quad$ 23(2), $\quad$ 182-185. $\quad$ Retrieved $\quad$ from http://search.proquest.com/docview/212246019/fulltextPDF/BED98C9D06324C9FPQ/1?accountid=14484

Fullerton, R. A. (2011). Historical methodology: The perspective of a professionally trained historian turned marketer. Journal of Historical Research in Marketing, 3(4), 436-448. http://dx.doi.org/10.1108/17557501111183608

Furman, J. L., Porter, M. E., \& Stern, S. (2002). The determinants of national innovative capacity. Research Policy, 31, 899-933. http://dx.doi.org/10.1016/S0048-7333(01)00152-4

Goldenberg, J., Lehmann, D. R., \& Mazursky, D. (2001). The idea itself and the circumstances of its emergence as predictors of new product success. Management Science, 47(1), 69-84. http://dx.doi.org/10.1287/mnsc.47.1.69.10670

Goldenberg, J., Mazursky, D., \& Solomon, S. (1999a). Toward identifying the inventive templates of new products: A channeled ideation approach. Journal of Marketing Research, 36(2), 200-210. http://dx.doi.org/10.1287/mnsc.47.1.69.10670

Goldenberg, J., Mazursky, D., \& Solomon, S. (1999b). Creative sparks. Science, 285(5433), 1495-1496. http://dx.doi.org/10.1126/science.285.5433.1495

Golder, P. N. (2000). Historical method in marketing research with new evidence on long-term market share stability. Journal of Marketing Research, 37(2), 156-172. http://dx.doi.org/10.1509/jmkr.37.2.156.18732

Golder, P. N., Shacham, R., \& Mitra, D. (2009). Innovations’ origins: When, by whom, and how are radical innovations developed? Marketing Science, 28(1), 166-179.

Gomes-Casseres, B., Hagedoorn, J., \& Jaffe, A. B. (2006). Do alliances promote knowledge flows? Journal of Financial Economics, 80(1), 5-33. http://dx.doi.org/10.1016/j.jfineco.2004.08.011

Gregan-Paxton, J., \& Roeder John, D. (1997). Consumer learning by analogy: A model of internal knowledge transfer. Journal of Consumer Research, 24(3), 266-284. http://dx.doi.org/10.1086/209509

Gregan-Paxton, J., Hibbard, J. D., Brunel, F. F., \& Azar, P. (2002). So that's what that is: Examining the impact of analogy on consumers' knowledge development for really new products. Psychology and Marketing, 19(6), 533-550. http://dx.doi.org/10.1002/mar.10023

Hall, B. H., Jaffe, A. B., \& Trajtenberg, M. (2002). The NBER Patent-Citation Data File: Lessons, insights, and methodological tools. In A. B. Jaffe \& M. Trajtenberg (Eds.), Patents, citations and innovations: A window on the knowledge economy (pp. 403-459). Cambridge, MA: The MIT Press.

Hargadon, A. B., \& Douglas, Y. (2001). When innovations meet institutions: Edison and the design of the electric light. Administrative Science Quarterly, 46(3), 476-501. http://dx.doi.org/10.2307/3094872

Kohli, R., Lehmann, D. R., \& Pae, J. (1999). Extent and impact of incubation time in new product diffusion. Journal of Product Innovation Management, 16(2), 134-144. http://dx.doi.org/10.1111/1540-5885.1620134

Lanjouw, J. O., \& Schankerman, M. (1999). The quality of ideas: Measuring innovation with multiple indicators. National Bureau of Economic Research, working paper 7345. http://dx.doi.org/10.3386/w7345

Lanjouw, J. O., \& Schankerman, M. (2004). Patent quality and research productivity: Measuring innovation with multiple indicators. The Economic Journal, 114(495), 441-465. http://dx.doi.org/10.1111/j.1468-0297.2004.00216.x

Lawrence, R. (1993). Inside new-product statistics: More, or less... new, or not? Journal of Advertising Research, 33(2), RC3-RC6. Retrieved from http://eds.b.ebscohost.com/ehost/pdfviewer/pdfviewer?sid=1f056747-c3ea-40a3-b03c-892c5063a060\%40se ssionmgr110\&vid $=1 \&$ hid $=112$

Marques, J. P. (2014). Closed versus open innovation: Evolution or combination? International Journal of Business and Management, 9(3), 196-203. http://dx.doi.org/10.5539/ijbm.v9n3p196

Moreau, P. C., Lehmann, D. R., \& Markman, A. B. (2001). Entrenched knowledge structures and consumer response to new products. Journal of Marketing Research, 38(1), 14-29. http://dx.doi.org/10.1509/jmkr.38.1.14.18836

Perks, H., \& Roberts, D. (2013). A review of longitudinal research in the product innovation field, with discussion of utility and conduct of sequence analysis. Journal of Product Innovation Management, 30(6), 1099-1111._http://dx.doi.org/10.1111/jpim.12048 
Qualls, W., Olshavsky, R. W., \& Michaels, R. E. (1981). Shortening of the PLC-An empirical test. Journal of Marketing Research, 45(4), 76-80. http://dx.doi.org/10.2307/1251474

Rosenzweig, S., \& Mazursky, D. (2008). A (Bumpy) ride on the innovation escalator: Historical trends of product innovativeness. Journal of Macromarketing, 28(1), 91-93.

Rosenzweig, S., \& Mazursky, D. (2014). Constraints of internally and externally derived knowledge and the innovativeness of technological output: The case of the United States. Journal of Product Innovation Management, 31(2), 231-246. http://dx.doi.org/10.1111/jpim.12092

Schultz, S. R., \& Rao, S. R. (1986). Product life cycles of durable goods for the home. Journal of the Academy of Management Science, 14(1), 7-12. http://dx.doi.org/10.1007/BF02722107

Smith, R. A., \& Lux, D. S. (1993). Historical method in consumer research: Developing causal explanations of change. Journal of Consumer Research, 595-610. http://www.jstor.org/stable/2489443

Sood, A., \& Tellis, G. J. (2005). Technological evolution and radical innovation. Journal of Marketing Research, 69(3), 152-168. http://dx.doi.org/10.1509/jmkg.69.3.152.66361

Sorescu, A. B., Chandy, R. K., \& Prabhu, J. C. (2007). Why some acquisitions do better than others: Product capital as a driver of long-term stock returns. Journal of Marketing Research, 44(1), 57-72. http://dx.doi.org/10.1509/jmkr.44.1.57

Szymanski, D. M., Kroff, M. W., \& Troy, L. C. (2002). Does product innovativeness really enhance performance? Proceedings of the American Marketing Association Conference, 13, 211.

Trajtenberg, M. (1990). A penny for your quotes: Patent citations and the value of innovations. RAND Journal of Economics, 21(1), 172-187. http://www.jstor.org/stable/2555502

Trajtenberg, M. (2001). A comparative analysis using patent data. Research Policy, 30, 363-389. http://dx.doi.org/10.1016/S0048-7333(00)00089-5

Van de Vrande, V. (2013). Balancing your technology-sourcing portfolio: How sourcing mode diversity enhances innovative performance. Strategic Management Journal, 34(5), 610-621. http://dx.doi.org/10.1002/smj.2031

Van Den Bulte, C. (2000). New product diffusion acceleration: Measurement and analysis. Marketing Science, 19(4), 366-380. http://dx.doi.org/10.1287/mksc.19.4.366.11795

Xie, X., \& Liu, F. (2015). Analysis on regional technology innovation efficiency evaluation and influence factors in China. International Journal of Business and Management, 10(3), 169-176. http://dx.doi.org/10.5539/ijbm.v10n3p169

\section{Copyrights}

Copyright for this article is retained by the author(s), with first publication rights granted to the journal.

This is an open-access article distributed under the terms and conditions of the Creative Commons Attribution license (http://creativecommons.org/licenses/by/3.0/). 